\title{
The Effect Of Credit To The Inflation Rate Through Gross Domestic Product In Indonesia Jurnal Ecces
}

\author{
Anas Iswanto Anwar ${ }^{1}$ \\ Ali Akbar ${ }^{2}$ \\ 1,2, Department of Economics, Hasanuddin University, Makassar \\ Perintis Kemerdekaan St. Km. 10, Tamalanrea, South Sulawesi \\ E-mail : aianwar@yahoo.com ${ }^{1}$, johntoteles@gmail.com
}

\section{Abstract: The Effect Of Credit To The Inflation Rate Through Gross Domestic Product In Indonesia}

\begin{abstract}
Credit markets are not always balanced because of unbalanced information and other causes. There are two credit channels that influence the transmission of monetary policy from finance to the real sector, namely bank credit channels that are more concerned with the behavior of banks that are more selective in credit selection because of asymmetric information. This study aims to determine the effect of credit that consists of investment credit, working capital credit and consumption credit to the inflation rate through Gross Domestic Product (GDP) in Indonesia. The overall data used in this study is secondary data from the result of systematic recording in the form of time series from 2007 to 2016 obtained from the Central Bureau of Statistics, Bank Indonesia Report and Indonesian Banking Statistics. Data were analyzed by using multiple regression with Ordinary Least Square (OLS) approach. Based on the results of the research, simultaneous credit has a positive and significant effect on inflation through GDP and partially found that investment credit and working capital credit have positive and significant effect to inflation through GDP, while consumption credit has positive and insignificant effect.
\end{abstract}

\section{Keywords: Investment Credit, Inflation, Gross Domestic Product}

\section{INTRODUCTION}

Inflation is an always interesting economic phenomenon discussed mainly related to its broad impact on the economy especially in Indonesia. On the monetary side, the central bank of the Republic of Indonesia issued a policy to control the inflation rate of the monetary sector, namely the transmission of monetary policy. The transmission mechanism 
of monetary policy basically illustrates how monetary policy pursued by the central bank influences various economic and financial activities so that in the end it can achieve its stated objectives. The transmission mechanism of monetary policy is a complex process, and therefore in monetary economic theory it is often called "black box" (Miskhin, 1995). Economists often refer to this as 'black box' because basically we know how monetary policy will influence economic growth and inflation but we never really know exactly how monetary policy affects economic growth and inflation. The effectiveness of monetary policy is very dependent on the transmission mechanism. There are several lines in the transmission mechanism of monetary policy, one of which is the credit line.

In the transmission mechanism of monetary policy through credit lines, the credit market greatly influences financial transmission from the monetary sector to the real sector. So that in this mechanism, it will be explained how the variable of bank credit affects the inflation rate through gross domestic product. Credit markets are not always balanced because of unbalanced information and other causes. There are two credit channels that influence the transmission of monetary policy from finance to the real sector, namely bank credit channels that are more concerned with the behavior of banks that are more selective in credit selection because of asymmetric information. The development of bank credit will affect inflation and real output through two things, namely investment development and consumption development. There are three types of loans channeled by banks based on their types of use, namely investment loans, working capital loans, and consumption loans.

Based on the monetary policy transmission mechanism, the focal point of Bank Indonesia as the Central Bank of the Republic of Indonesia is the stabilization of the inflation rate. However, the mechanism is considered a complex process with various channels. Therefore, this study was conducted using one of the lines, namely the credit line to influence the stabilization of the inflation rate. The title of this research is "Analysis of the Effect of Credit on Inflation Rate through Gross Domestic Product in Indonesia for the Period 2007-2016". 


\section{LITERATURE REVIEW}

\section{Monetary Policy Transmission}

The transmission mechanism of monetary policy basically illustrates how monetary policy pursued by the central bank influences various economic and financial activities so that in the end it can achieve its stated objectives. Specifically, Taylor (1995) states that the transmission mechanism of monetary policy is "the process through monetary decisions that are transmitted into changes in real GDP and inflation". The transmission mechanism of monetary policy starts from the actions of the central bank by using monetary instruments that influence economic and financial activities through various transmission channels of monetary policy, such as money channels, credit, interest rates, exchange rates, asset prices and expectations. In the financial sector, monetary policy influences the development of interest rates, exchange rates and stock prices in addition to the volume of public funds deposited in banks, loans channeled to the business world and investment in bonds, stocks and other securities. In the real sector, this policy influences the development of consumption, investment, exports and imports so that monetary policy influences economic growth and inflation which is the ultimate target of the policy. The transmission mechanism of monetary policy is a complex process, and therefore in monetary economic theory it is often called "black box" (Miskhin, 1995).

\section{Credits}

Credit is a financial facility that allows a person or business entity to borrow money to buy a product and repay it within a specified period of time. Credit comes from the word credere which means trust, the point is that if someone obtains credit, then the person has been given trust. As for the lender, it means that he has given confidence that the money that has been loaned will return.

From the point of view of using credit, include:

a) Consumer loans are loans used by borrowers for consumption purposes or for fulfilling daily needs.

b) Working capital loans are loans intended for production purposes which will be used for business expansion. 
c) Investment loans are medium-term loans for the purchase of capital goods and services used to rehabilitate, modernize or establish new businesses.

\section{Gross Domestic Product}

According to A. Mc Eachern (2000) gross domestic product means measuring the market value of the final goods and services produced by resources that are in a country for a certain period of time, usually one year. GDP can also be used to study the economy from time to time or to compare several economies at a time. Gross domestic product only includes final goods and services, namely goods and services sold to the last user. For goods and services purchased to be processed and then sold again not included in the GDP count, this is done to avoid the problem of double counting (A. McEachern, 2000). Double calculations can cause the results of the GDP calculation not to show the actual results, so that in this calculation only one calculation is made for each product. According to Mankiw (2007) there are two types of GDP, namely as follows:

1. GDP with current prices or nominal GDP, that is, the value of goods and services produced by a country in a year is valued according to the prices prevailing in that year.

2. GDP with a fixed price or real GDP, that is, the value of goods and services produced by a country in a year is valued according to the prices prevailing in a given year which are then used to assess goods and services produced in other years.

\section{Inflation}

Inflation is an event that describes a situation and condition where the price of goods increases and the value of the currency weakens, and if it occurs continuously it will result in a deterioration in the overall economic condition and be able to shake the political order of a country. Inflation is defined as an increase in the overall price level in an economy (Mankiw, 2003).

The occurrence of inflation is a result of an increase in the price level above the generally accepted average which can be measured by the price index of consumer goods from year to year. Another definition of inflation is the tendency of prices to rise in general 
Anas, Akbar, The Effect Of Credit To The Inflation Rate Through Gross Domestic Product In Indonesia.

and continuously (Boediono, 1989). The price increase of just one or two items is not called inflation, unless the increase extends to a large part of the price of other goods. Inflation is a condition that is caused by the absence of a balance between the demand for goods and supplies, namely demand exceeds inventory and the greater the difference the greater the danger posed by inflation for the health of the economy (Soesastro, 2005).

\section{RESEARCH METHODOLOGY}

This research was conducted by covering all regions of Indonesia. The data used in the study are secondary data, namely data relating to investment credit data, working capital credit data, consumption credit data, GDP data and inflation rate data for the period 2007 - 2016. The data for all variables to be examined starts from the first quarter of the year 2007 to IV quarter 2016 with the amount of data (n) is 40 periods. This data is collected in a continuous time interval (time series). This data was obtained through the Office of BPS (Central Bureau of Statistics), Indonesian Banking Statistics from the web of the Financial Services Authority (OJK) and the Indonesian Economic and Financial Statistics (SEKI) Bank Indonesia. In addition, literature studies are also conducted (journals, books, internet articles, and various other literature) that are related and relevant to the problems under study.

The data analysis model used in this study is a multiple linear analysis model using the Analysis Eviews 9.0 Enterprise analysis tool. The multiple regression analysis model is used to measure the influence of more than one independent variable or independent variable on the dependent variable or dependent variable. Then to estimate parameters in multiple linear regression models, structural methods are used. To see the extent to which the factors of investment credit, working capital credit and consumption credit influence the inflation rate through GDP in Indonesia, the analysis of the regression model is stated as follows:

$$
\begin{aligned}
& Y 1=f(X 1, X 2, X 3) \\
& Y 2=f(Y 1)
\end{aligned}
$$


Or by using the general form of multiple linear regression models in the following equation:

$Y 1=a 0+a 1 X 1+a 2 X 2+a 3 X 3+\mu 1$

$\mathrm{Y} 2=\beta 0+\beta 1(\mathrm{Y} 1)+\mu 2$

found the new equation as follows:

$Y 2=\beta 0+\beta 1(a 0+a 1 X 1+a 2 X 2+a 3 X 3+\mu 1)+\mu 2$

$Y 2=(\beta 0+a 0 \beta 1)+(a 1 \beta 1) X 1+(a 2 \beta 1) X 2+(a 3 \beta 1) X 3+(\beta 1 \mu 1+\mu 2)$

Where:

Y1 = Gross Domestic Product (Rupiah)

Y2 = Inflation Rate (Percent)

$\mathrm{X} 1=$ Investment Credit (Rupiah)

X2 = Working Capital Credit (Rupiah)

X3 = Consumer Credit (Rupiah)

$a 0, \beta 0,(\beta 0+a 0 \beta 1)=$ Constants

$\mu 1 \& \mu 2=$ Error term

a1 = Effect of investment credit on GDP

a2 = Effect of Working Capital Credit on GDP

a3 = Effect of Consumer Credit on GDP

a1 $\beta 1=$ Effect of Investment Credit on Inflation through GDP

a2 $\beta 1$ = Effect of Working Capital Credit on Inflation through GDP 
Anas, Akbar, The Effect Of Credit To The Inflation Rate Through Gross Domestic Product In Indonesia.

a3 $\beta 1=$ Effect of Consumer Credit on Inflation through GDP

The test criteria carried out on the equation model are by using statistical testing, including testing the partial regression coefficient ( $\mathrm{t}$ test), testing the coefficient of determination (R2) and testing the regression coefficient together ( $F$ test).

\section{RESULTS}

\section{Results of Estimated Effects of Investment Credit (X1), Working Capital Credit (X2) and Consumption Credit (X3) on GDP (Y1) in Indonesia Period 2009-2016}

The data analysis technique used in this study is multiple linear regression, namely the regression equation involving 2 (two) or more variables. This analysis is used to determine the magnitude of the influence of a dependent variable on the independent variable. The regression results of the effect of investment credit (X1), working capital credit (X2) and consumption credit (X3) on GDP in Indonesia (Y1) for the period 2007-2016 using the Eviews version 9.0 software obtained the following regression results.

The results of statistical tests show that the investment credit variable (X1) has a probability value of less than five percent, which is equal to 0.0010 . This concludes that the investment credit variable has a significant effect on GDP. In addition, it can also be known that the coefficient value is 0.077470 which means that each increase in investment credit by one percent will have a positive effect of 0.077470 percent of GDP (Y1). The results of statistical tests also show that the working capital credit variable (X2) has a probability level below five percent which is equal to 0.0237 with a coefficient of 0.151714 , meaning that each percentage increase in the percentage of working capital loans significantly increases GDP by 0.151714 percent.

However, the results of statistical tests that show the consumption credit variable (X3) has a probability level above five percent which is equal to 0.2431 with a coefficient of 0.068387 , it can be said that the increase in the percentage of consumption credit does not significantly influence the increase in GDP. 
Table 1. Regression Results Effect of Investment Credit (X1), Working Capital Credit (X2) and Consumption Credit (X3) on GDP in Indonesia (Y1) Period 2007 - 2016

\begin{tabular}{lcccr}
\hline \multicolumn{5}{c}{ Dependent Variabel : Gross Domestic Product $\left(\mathrm{Y}_{1}\right)$} \\
\hline \multicolumn{1}{c}{ Variable } & Coefficient & Std. Error & t-Statistic & \multicolumn{1}{c}{ Prob. } \\
\hline C & 25.26975 & 0.339893 & 74.34622 & 0.0000 \\
X1 & 0.077470 & 0.021558 & 3.593493 & 0.0010 \\
X2 & 0.151714 & 0.064250 & 2.361298 & 0.0237 \\
X3 & 0.068387 & 0.057397 & 1.191486 & 0.2431 \\
R-squared & 0.981625 & Mean dependent var & 35.16133 \\
Adjusted R-squared & 0.980094 & S.D. dependent var & 0.160177 \\
S.E. of regression & 0.022599 & Akaike info criterion & -4.647185 \\
Sum squared resid & 0.018386 & Schwarz criterion & -4.478297 \\
Log likelihood & 96.94371 & Hannan-Quinn criter. & -4.586121 \\
F-statistic & 641.0774 & Durbin-Watson stat & 1.625376 \\
Prob(F-statistic) & 0.000000 & & & \\
N = 40 & & &
\end{tabular}

\section{Results of Estimated Effect of GDP (Y1) on Inflation (Y2) in Indonesia Period} 2007-2016

To find out the effect of gross domestic product on inflation in Indonesia, the results of regression calculations are obtained using the program Eviews 9.0 in Table 2 as follows:

Table 2. Results of Regression on the Effect of GDP (Y1) on Inflation (Y2) in Indonesia, Period $2007-2016$

\begin{tabular}{lrrrr}
\hline \multicolumn{5}{c}{ Dependent Variabel : Inflation (Y2) } \\
\hline \multicolumn{1}{c}{ Variable } & Coefficient & Std. Error & t-Statistic & \multicolumn{1}{c}{ Prob. } \\
\hline \multicolumn{1}{c}{ C1AADJ } & -4516.189 & 69.26370 & -65.20282 & 0.0000 \\
R-squared & 131.4052 & 1.969863 & 66.70778 & 0.0000 \\
Adjusted R-squared & 0.991533 & Mean dependent var & 104.1938 \\
S.E. of regression & 0.991310 & S.D. dependent var & 20.94263 \\
Sum squared resid & 1.952273 & Akaike info criterion & 4.224572 \\
Log likelihood & 144.8321 & Schwarz criterion & 4.309016 \\
F-statistic & -82.49145 & Hannan-Quinn criter. & 4.255105 \\
Prob(F-statistic) & 4449.928 & & Durbin-Watson stat & 0.985856 \\
N = 40 & 0.000000 & & & \\
\cline { 1 - 1 } & & & &
\end{tabular}


Anas, Akbar, The Effect Of Credit To The Inflation Rate Through Gross Domestic Product In Indonesia.

Based on Table 2 the results of the regression analysis of the effect of GDP on inflation, the value of R2 $=0.991533$ is obtained. The coefficient value of R2 indicates that the variation in the change in inflation value can be explained by GDP by 99 percent. The Fstatistic value is 4449,928 with a probability value of 0.000000 , smaller than the significance level of five percent. So it can be said that GDP affects inflation. The results of statistical tests show that the GDP variable has a probability value smaller than the maximum error limit that can be tolerated at five percent which is 0.0000 . So, it can be concluded that the GDP variable significantly has a positive effect on inflation in Indonesia. Besides that, it can also be known that the coefficient value is 131,4052 , which means that every increase in economic growth by one percent will have a positive effect of 131,4052 against inflation.

\section{Results of Estimated Effects of Investment Credit (X1), Working Capital Credit (X2) and Consumer Credit (X3) on Inflation (Y2) through GDP (Y1) in Indonesia}

\section{Period 2007-2016}

To find out the effect of investment credit, working capital credit and consumption credit on inflation through GDP in Indonesia obtained by using a manual count taken from the calculation of the regression results in Table 1 multiplied by the regression results in Table 2, the results are as follows:

Table 3. Results of Estimated Effects of Investment Credit (X1), Working Capital Credit (X2) and Consumption Credit (X3) on Inflation (Y2) through GDP (Y1)

in Indonesia Period 2007-2016

\begin{tabular}{cccc}
\hline Influence & Through Y1 & $\begin{array}{c}\text { Indirect } \\
\text { Effecta }\end{array}$ & Description \\
\hline X1 to Y2 & $\mathrm{a}_{1} \beta_{1}(0.077470 \times 131.4052)$ & 10.17996084 & Significant \\
X2 to Y2 & $\mathrm{a}_{2} \beta_{1}(0.151714 \times 131.4052)$ & 19.93600851 & Significant \\
X3 to Y2 & $\mathrm{a}_{3} \beta_{1}(0.068387 \times 131.4052)$ & 8.986407412 & Not Significant \\
\hline
\end{tabular}

Table 3 above explains that the effect of investment credit on the inflation index through GDP gets results that state the significance of these variables. The coefficient value is 10.17996084 which means that every one percent increase in investment credit will increase the inflation percentage by 10.17996084 percent. This indicates that the investment credit variable has a positive and significant effect on inflation through GDP in 
Indonesia for the period 2007-2016. The results of the manual test show that the working capital credit) variable has a coefficient (bfl) 19.93600851 . This illustrates that every one percent increase in working capital loans will increase inflation in Indonesia by 19.93600851 percent. So it can be concluded that the working capital credit variable also has a positive and significant effect on inflation through GDP in Indonesia for the period 2007-2016. However, the consumption credit variable shows different results on the effect on inflation through GDP. The consumption credit variable has a coefficient of 8.986407412 , but the results obtained are not significant even though it has a positive effect. Then it can be said that the consumption credit variable has a positive and not significant effect on inflation through GDP in Indonesia for the period 2007-2016.

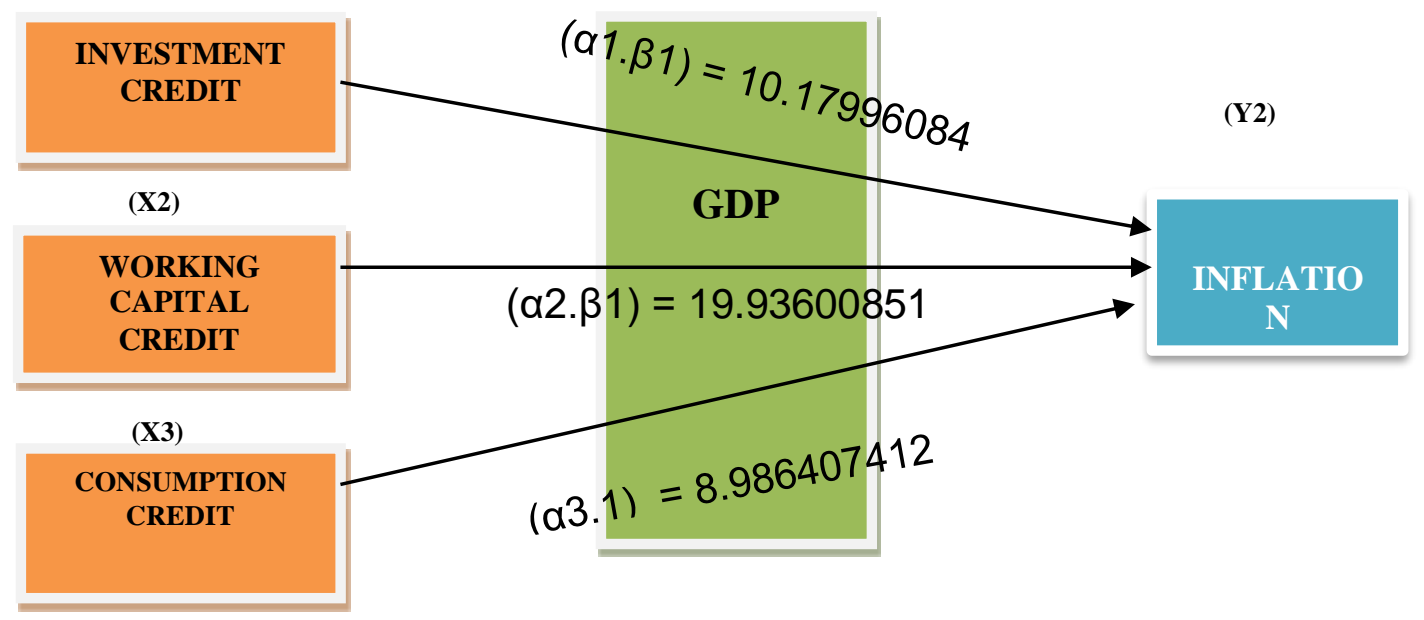

Figure 1. Illustration of Results Estimated Effect of Investment Credit (X1),

Working Capital Credit (X2) and Consumption Credit (X3) on Inflation (Y2) through GDP (Y1) in Indonesia Period 2007-2016

\section{DISCUSSION}

Based on the results of the estimation and analysis of the data above, further explanation is the implications of the factors that influence inflation in Indonesia. The results of the analysis referred to along with findings from previous studies are as follows: 
Anas, Akbar, The Effect Of Credit To The Inflation Rate Through Gross Domestic Product In Indonesia.

\section{Effect of Investment Credit on GDP in Indonesia}

Based on the estimation results of the study, the investment credit variable has a significant effect with a probability value below $5 \%$ which is 0.0010 , and has a positive effect on GDP in Indonesia with a coefficient value of 0.07747 which means that every one percent increase in investment credit is accompanied by an increase in GDP of 0.07747 percent. These results are also reinforced by Harrod-Domar's theory of economic growth stating that investment plays an important role in the process of a country's economic growth. The role of investment in growth is to create a revenue side, meaning that investment affects the demand side. Both investments can increase economic production capacity by increasing capital stock, meaning that investment will affect the supply side. When investment credit is increased, it means that the community will be more productive by opening new business fields, expanding business fields and increasing production on the other hand with increasing investment credit distribution, community income will also increase due to increased business volume so that eventually it will increase national income - These results are in accordance with the initial hypothesis which states that there is a positive and significant relationship between investment credit to GDP but is not in line with the research conducted by Nurhayati (2017) which states that an increase in investment credit will negatively and significantly increase the gross domestic product increase.

\section{Effect of Working Capital Loans on GDP in Indonesia}

Based on the results of the research estimation, the working capital credit variable has a significant effect with a probability value below $5 \%$ which is 0.0237 , and has a positive effect on GDP in Indonesia with a coefficient of 0.151714 which means that every one percent increase in working capital credit is accompanied by a GDP increase of 0.151714 percent. These results are in accordance with the initial hypothesis which states that there is a positive and significant relationship between working capital loans to GDP. This is in line with the research conducted by Nurhayati (2017) which states that an increase in working capital loans will positively and significantly affect the increase in gross domestic product.

\section{Effect of Consumer Loans on GDP in Indonesia}

Based on the results of the research estimation, the consumption credit variable has no significant effect with a probability value above $5 \%$, which is 0.2413 , but positive for GDP in Indonesia with a coefficient value of 0.068387 which means that every one percent 
increase in consumption credit is accompanied by a 0.068387 percent increase in GDP. These results are not in accordance with the initial hypothesis which states that there is a positive and significant relationship between consumption credit to GDP. This is in line with the research conducted by Nurhayati (2017) which states that an increase in consumer credit will positively and not significantly increase the gross domestic product. Although it has a positive effect, consumption credit does not have a significant effect on GDP in Indonesia. This is due to changes in the consumption patterns of people who tend to be consumptive, for example using consumer loans for the purchase of private and home vehicles, even though banks, especially Bank Indonesia, have addressed the consumptive symptoms by regulating policies related to consumption credit but not enough to control the increasingly consumptive.

\section{Effects of GDP on Inflation in Indonesia}

Based on the results of the research estimation, the GDP variable has a significant effect with a probability value below $5 \%$ which is 0.0000 , and has a positive effect on inflation in Indonesia with a coefficient of 131.4052 which means that every one percent increase in GDP is accompanied by an increase of 131.4052 percent. The results of the estimation of this study are reinforced by Keynesian theory which states that an increase in GDP on the expenditure side will increase the effective demand of society. If the amount of effective demand for commodities increases, at the prevailing price level, exceeding the maximum amount of goods that can be produced by the community, the inflationary gap will arise and cause a problem of inflation. However, these results are not in line with the research conducted by Sipayung (2013) which states that GDP does not affect Inflation.

\section{Effect of Investment Credit on Inflation through GDP in Indonesia}

Based on the estimation results of the study, the investment credit variable has a significant effect with a probability value below $5 \%$ which is 0.0010 , and has a positive effect on inflation through GDP in Indonesia with a coefficient of 10.17996084 which means that every one percent increase in investment credit is accompanied by an increase in inflation by 10.17996084 percent. This is in line with the previously made hypothesis which states that investment credit has a positive and significant effect on inflation through GDP. 
Anas, Akbar, The Effect Of Credit To The Inflation Rate Through Gross Domestic Product In Indonesia.

As it is known that directly increasing the amount of credit also increases the money supply, the results of this estimation are in line with the research conducted by Sutawijaya (2012) which states that the money supply has a positive effect on inflation. However, the estimation results are also not in line with Utami's (2012) research, Hartomo (2010) and Sipayung (2013) which states that the money supply does not have a significant effect on inflation.

\section{Effects of Working Capital Loans on Inflation through GDP in Indonesia}

Based on the results of the research estimation, the working capital credit variable has a significant effect with a probability value below $5 \%$ which is 0.0237 , and has a positive effect on inflation through GDP in Indonesia with a coefficient of 19.93600851 which means that every one percent increase in working capital credit is accompanied by an increase in inflation through GDP of 19,93600851 percent. This is in line with the previously made hypothesis which states that working capital credit has a positive and significant effect on inflation through GDP. As it is known that directly increasing the amount of credit also increases the money supply, the results of this estimation are in line with the research conducted by Sutawijaya (2012) which states that the money supply has a positive effect on inflation. However, the estimation results are also not in line with Utami's (2012) research, Hartomo (2010) and Sipayung (2013) which states that the money supply does not have a significant effect on inflation.

\section{Effects of Consumer Loans on Inflation through GDP in Indonesia}

Based on the estimation results, the consumption credit variable has no significant effect with a probability value above $5 \%$, which is 0.2413 , but has a positive effect on inflation through GDP in Indonesia with a coefficient value of 8.986407412 which means that every one percent increase in consumption credit is accompanied by an increase in inflation through 8.986407412 percent. The insignificant effect of consumption credit on inflation through GDP is due to the consumption pattern of consumers who tend to be consumptive as used to buy private vehicles or private homes. Although it has a positive, but not significant effect due to the consumptive pattern, it is contrary to the increase in investment credit, which reflects the increase in GDP through its contribution in increasing business income in Indonesia. This is not in line with the previously made hypothesis which 
states that consumption credit has a positive and significant effect on inflation through GDP. As it is known that directly increasing the amount of credit also increases the money supply, the results of this research estimate are in line with the research conducted by Utami (2012), Hartomo (2010) and Sipayung (2013) which states that the money supply has no significant effect on inflation, and in line with Sutawijaya's (2012) research which states that the money supply has a positive effect on inflation.

\section{CONCLUSION}

Based on the results of research conducted and discussed in - in the previous, the authors can draw conclusions:

1. Taken together, investment credit, working capital credit and consumption credit have a positive and significant effect on GDP in Indonesia during the study period. Partially, investment credit and working capital loans have a positive and significant effect on GDP, while consumption credit has a positive and not significant effect on GDP in Indonesia.

2. Taken together, investment credit, working capital credit and consumption credit have a positive and significant effect on inflation through GDP in Indonesia during the study period. Partially, investment credit and working capital loans have a positive and significant effect on inflation through GDP, while consumption credit has a positive and insignificant effect on inflation through GDP in Indonesia.

Based on the results of the research conducted, several suggestions were proposed:

1. In general, with a credit level that tends to increase, it can have a positive influence on the increase in GDP during the study period. The increasing number of investment loans and working capital loans during the study period can encourage increased production which can support economic growth in Indonesia. Based on this, it is expected that the government will continue to encourage the increase in credit. However, especially for consumer loans, regulations should be made so that their use is more productive in order to encourage a more massive increase in GDP.

2. To Bank Indonesia it is recommended that steps be taken to anticipate an increase in the rate of investment credit and uncontrolled working capital loans so as to trigger an increase in inflation. 
Anas, Akbar, The Effect Of Credit To The Inflation Rate Through Gross Domestic Product In Indonesia.

\section{REFERENCES}

McEachern, William. 2000. Ekonomi Makro: Pendekatan Kontemporer. Salemba Empat. Jakarta.

Anwar, Anas Iswanto. 2017. Bank dan Lembaga Keuangan Lainnya. Penerbit: Departemen Ilmu Ekonomi FEB Universitas Hasanudin. Makassar.

Arsyad, Lincolin. 1997. Ekonomi Pembangunan. Edisi Kelima. STIE YKPN Yogyakarta.

Boediono. 1992. Ekonomi Makro. BPFE UGM. Yogyakarta.

Debelle, Guy. 2004. Household Dept and The Macroeconomy. BIS Quarterly Review.

Dede, Hijriani. 2016. Analisis Pengaruh Jumlah Uang Beredar Terhadap Inflasi Dan Inflasi Terhadap Pertumbuhan Ekonomi Di Indonesia. Diploma thesis, Universitas Andalas.

Gujarati, Damodar N. 2010. Dasar-dasar Ekonometrika. Salemba Empat. Jakarta.

Hanafi. 2011. Mekanisme Transmisi Kebijakan Moneter. Diunduh 1 April 2017, dari http://hanafithanasevi.blogspot.co.id/2011/07/mekanisme-transmisikebijakan moneter.html.

Hartomo, Hario Aji. 2010. Pengaruh Jumlah Uang Beredar dan Kurs terhadap Inflasi di Indonesia Sebelum dan Sesudah Krisis Global 2008. Media Ekonomi, Vol. 18 No. 3.

Hera, dkk. 2000. Indikator-indikator Makroekonomi. Fakultas Ekonomi Universitas Indonesia. Jakarta.

Jhingan. 2008. Ekonomi Pembangunan Perencanaan. Raja Grafindo. Persada. Jakarta.

John B. Taylor. 1995. The Monetary Transmission Mechanism: An Empirical Framework. Journal of Economic Perspectives, American Economic Association, Vol. 9 no. 4.

Kasmir. 2008. Bank dan Lembaga Keuangan Lainnya. Edisi Revisi 2008. PT. RAJAGRAFINDO PERSADA. Jakarta.

Miskhin, Frederic S. 1995. The Economics of Money Banking and Financial Markets. Edisi Keempat. Haper Collins College Publisher.

Mankiw, N. Gregory. 2007. Makroekonomi. Edisi Keenam. Erlangga. Jakarta.

Nurhayati, dan Nurjannah. 2017. Pengaruh Penyaluran Kredit Investasi, Kredit Modal Kerja dan Kredit Konsumtif terhadap Pertumbuhan Ekonomi Indonesia. Jurnal Samudra Ekonomi dan Bisnis, Vol. 8, No. 1.

Pratiwi, Ardianing. 2013. Determinan Inflasi di Indonesia: Analisis Jangka Panjang dan Pendek. Jurnal Ilmiah Fakultas Ekonomi dan Bisnis Universitas Brawijaya Malang.

Rahardja, Pratama. 2008. Mandala Manurung. Teori Ekonomi Makro: Suatu Pengantar. Lembaga Penerbit FE UI. 
Setiawan, Iwan. 2009. Analisis Dampak Kebijakan Moneter terhadap Perkembangan Inflasi dan Pertumbuhan Ekonomi di Indonesia. Jurnal Ekonomi, Keuangan, Perbankan dan Akuntansi, Vol. 1 No. 1.

Sipayung, Putri Tirta Enistin, dan Made Kembar Sri Budhi. 2013. Pengaruh PDB, Nilai Tukar dan Jumlah Uang Beredar terhadap Inflasi di Indonesia periode 1993-2012. E-Jurnal Ekonomi Pembangunan Universitas Udayana, Vol. 2 No. 7.

Soesastro. 2005. Pemikiran dan Permasalahan Ekonomi di Indonesia dalam Setengah Abad Terakhir Jilid I (1945-1959). Kanisius. Jakarta.

Sukirno, Sadono. 2004. Makroekonomi, Teori Pengantar; Edisi Ketiga. Rajawali Press. Jakarta.

Sukirno, Sadono. 2006. Ekonomi Pembangunan Proses Masalah dan Dasar Kebijakan. Cetakan Ketiga. Penerbit Kencana. Jakarta.

Sutawijaya, Adrian, dan Zulfahmi. 2012. Pengaruh Faktor-Faktor Ekonomi terhadap Inflasi di Indonesia. Jurnal Organisasi dan Manajemen, Vol. 8 No. 2.

Todaro, Michael P. 2006. Pembangunan Ekonomi di Dunia Ketiga. Erlangga. Jakarta.

Utami, Annisa Tri, dan Daryono Soebagiyo. 2013. Penentu Inflasi di Indonesia; Jumlah Uang Beredar, Nilai Tukar ataukah Cadangan Devisa?. Jurnal Ekonomi dan Studi Pembangunan, Vol. 14 No. 2.

Warjiyo, Perry. 2004. Mekanisme transmisi Kebijakan Moneter di Indonesia. Pusat pendidikan dan Studi Kebanksentralan (PPSK). Jakarta. 